\title{
Nucleotide Sequence and RT-PCR Detection of a Virus Associated with Grapevine Rupestris Stem-Pitting Disease
}

\author{
Yun-Ping Zhang, Jerry K. Uyemoto, Deborah A. Golino, and Adib Rowhani
}

Department of Plant Pathology, One Shields Avenue, University of California, Davis 95616.

Accepted for publication 7 August 1998.

\begin{abstract}
Zhang, Y.-P., Uyemoto, J. K., Golino, D. A., and Rowhani, A. 1998. Nucleotide sequence and RT-PCR detection of a virus associated with grapevine rupestris stem-pitting disease. Phytopathology 88:1231-1237.

Grapevine rupestris stem pitting (RSP) is a graft-transmissible disease of unknown etiology. We have characterized a virus associated with this disease. The entire genomic sequence (GenBank accession number AF026278) consisted of 8,725 nucleotides excluding a poly(A) tail. Six open reading frames (ORF) were found. ORF1 potentially encodes a polypeptide with a methyltransferase domain, a papain-like proteinase domain, a helicase

and ORF4 compose a triple-gene block; ORF5 encodes a coat protein; and ORF6 is located near the 3' end with unknown function. Sequence analysis indicated that the virus is most similar to apple stem-pitting virus and may be allied with the carla- and potexviruses and grouped with other viruses that infect woody hosts. A specific reverse-transcription polymerase chain reaction (RT-PCR)-based detection method was developed. Among 62 grapevine sources known to be infected with rupestris stem-pitting disease, 60 sources tested positive by RT-PCR. Among 43 healthy vines tested, all were negative. The name grapevine rupestris stem-pitting-associated virus is proposed.
\end{abstract} domain, and a RNA-dependent RNA polymerase domain; ORF2, ORF3,
Grapevine rupestris stem pitting (RSP) is a graft-transmissible disease first reported in Italy $(10,22)$ and later recognized elsewhere (2,13). The disease was found in California in 1971 (24) and was later reported in a high percentage of Vitis vinifera selections imported from western Europe and Australia (19).

RSP causes a slow decline in the growth of grapevines and, after several years, affected vines are reported to be smaller than healthy ones. Limited research documenting these effects on different grapevine species and cultivars have been published, so it is difficult to assess the magnitude of the effect of this disease on grape production $(12,17,18,39)$. Currently, RSP is detected by indexing on $V$. rupestris cv. St. George. Symptoms include small pits on the woody cylinder immediately below the inoculum chip bud, but occasionally pits and grooves have occurred elsewhere on the woody cylinder.

Various studies have been conducted to determine the causal agent of RSP. In 1980, a closterovirus with 800-nm flexuous filamentous particles was isolated from one diseased grapevine (11), but its relationship to RSP was not determined. Later, a doublestranded RNA (dsRNA) species of $359 \mathrm{bp}\left(0.24 \times 10^{6} \mathrm{Da}\right)$ was isolated specifically from diseased grapevines (36). In addition, two dsRNA species of $5.3 \times 10^{6}$ and $4.4 \times 10^{6} \mathrm{Da}$ were found to be associated with the disease (4). Walter and Cameron (50) also recovered a dsRNA species of $5.5 \times 10^{6} \mathrm{Da}$ and proposed dsRNA analysis as a tool for the detection of RSP. Meng and Gonsalves (35) reported on the nucleotide sequence of a virus associated with RSP and stated that the characterized virus was similar to apple stem-pitting virus and potexviruses.

In this paper, we report the cloning, sequencing, and characterization of the genome of a virus associated with RSP, hereafter referred to as grapevine rupestris stem-pitting-associated virus (GRSPaV). We have determined the genome organization of this virus and found it to be most similar to apple stem-pitting virus by phylogenetic

Corresponding author: A. Rowhani; E-mail address: akrowhani@ucdavis.edu

Publication no. P-1998-0922-03R

(C) 1998 The American Phytopathological Society analysis of replicase and coat protein amino acid sequences. Development of a rapid reverse-transcription polymerase chain reaction (RT$\mathrm{PCR}$ ) assay for its detection in infected vines is also presented.

\section{MATERIALS AND METHODS}

Virus sources and dsRNA isolation. The GRSPaV-infected grapevines used in this study were own-rooted cuttings of the original grapevines that had tested positive when indexed by graft-transmission on the RSP indicator, V. rupestris cv. St. George. The propagation was done because the original vineyard containing these biologically indexed grapevines was being moved to a new site. Healthy controls were comprised of 23 grapevines of different $V$. vinifera cultivars (all were negative when indexed on 'St. George') and 20 hybrids derived from seedling populations from a rootstock breeding program using diverse Vitis spp. (provided by M. A. Walker, Department of Viticulture and Enology, University of California, Davis). RSP is not known to be seedborne.

For cDNA cloning (described below), dsRNA was extracted from bark scrapings of a known RSP-diseased grapevine ( $V$. vinifera cv. Cabernet Sauvignon) as described by Valverde (49). For RT-PCR assays, dsRNAs were extracted using a small-scale extraction procedure described elsewhere (54).

cDNA cloning and sequence analysis. For cloning the major portion of the virus genome sequence, cDNA was synthesized and cloned from the dsRNA template using random primers and the Superscript II cDNA synthesis and plasmid cloning kit (Gibco BRL, Gaithersburg, MD) following the manufacturer's recommendations. For cloning the $5^{\prime}$ - and $3^{\prime}$-end sequences, the virus-specific primer RSP1 (5' TTTACAGACTGGATGTGAGT 3') and the oligo $\mathrm{d}(\mathrm{T})$ primer (Clontech Labs Inc., Palo Alto, CA) were used, respectively, to prime cDNA syntheses. The 5'-PCR primer (Clontech Labs Inc.)/RSP1 and the virus-specific primer RSP7 (5' TTCCCTTTCCATGCTAAATC $3^{\prime}$ )/CDS/3'-PCR primer (Invitrogen Corp., Carlsbad, CA) were used to amplify the $5^{\prime}$ - and $3^{\prime}$-end sequences, respectively, using the Smart PCR cDNA library construction kit (Clontech Labs Inc.). The synthesized cDNAs were cloned using the original TA cloning kit (Invitrogen Corp.) following the manu- 
facturer's recommendations. cDNA clones were sequenced (AGI Prism 377 DNA sequencer; Perkin-Elmer, Foster City, CA) at the University of California, Davis, using both universal and virusspecific primers. Multiple overlapping clones were sequenced from both directions to ensure accuracy of the sequences. The sequences were analyzed using the Wisconsin GCG software package (Genetic Computer Group, Madison, WI).

Sequence comparison and phylogenetic analysis. The $5^{\prime}$ - and $3^{\prime}$-end sequences were compared with those of carlaviruses using the PileUp program of GCG with a gap weight of 5 and a gap length weight of 3 . Phylogenetic analysis was also performed to determine the relationship of GRSPaV to other filamentous plant viruses. A sequence of about 300 amino acids around the two core sequences (GxxxTxxxNT/S and GDD) of the putative RNA-dependent RNA polymerase, which is near the $\mathrm{C}$ terminus and includes the eight conserved motifs described by Koonin (29), was selected for the comparison. The following viruses were included in the analysis: apple chlorotic leaf spot trichovirus (ACLSV, D14996) (43), apple stem-grooving capillovirus (D14995) (51), apple stem-pitting virus (ASPV, D21829) (27), beet yellows closterovirus (X73476) (1), blueberry scorch carlavirus (BSV, L25658) (8), chrysanthemum virus B carlavirus (CVB, S60150) (32), citrus tristeza closterovirus (U16304) (28), clover yellow mosaic potexvirus (CYMV, D29630) (45), narcissus mosaic potexvirus (NMV, D13747) (55), papaya mosaic potexvirus (PMV, D13957) (44), potato virus M carlavirus (PVM, X53062) (52), potato virus S carlavirus (PVS, D00461) (33), potato virus X potexvirus (PVX, D00344) (25), potato virus Y potyvirus (M95491) (48), tobacco etch potyvirus (M15239) (3), white clover mosaic potexvirus (WCIMV, X16636) (6), and tobacco mosaic tobamovirus (D13438) (26) as the outgroup. The sequences were aligned using the PileUp program with a gap weight of 2 and a gap length weight of 1 . The sequence alignment was then analyzed by PAUP (Phylogenetic Analysis Using Parsimony) version 3.1.1 (Illinois Natural History Survey, Champaign, IL). A phylogram was created using bootstrap analysis of 100 replicates with 10 random additions per replicate. Branch swapping was done by the tree bisection and reconnection method. Phylogenetically uninformative bases were excluded.

Further comparisons of amino acid sequences of coat protein were also made to the following viruses using the same program: ASPV (D21829) (27), BSV (L25658) (8), CVB (S60150) (32), CYMV (D29630) (45), cymbidium mosaic potexvirus (X62133) (9), foxtail mosaic potexvirus (M62730) (5), helenium S carlavirus (D10454) (14), lily symptomless carlavirus (D43801) (46), lily X potexvirus (X15342) (34), NMV (D13747) (55), PMV (D13957) (44), PVM (X53062) (52), PVS (S45593) (15), PVX (D00344) (25), WCIMV (X16636) (6), and ACLSV (M58152) (16) as the outgroup. The sequences were analyzed the same way as above, except with a gap weight of 3 and gap length weight of 1 .

PCR and virus detection. Oligonucleotide primers were designed from sequences in different regions of the genome and manufactured by Gibco BRL. Two primer pairs used were RSP2 forward primer (5' CAAGCATGCTCTTGGCAAC 3') and RSP21 reverse primer (5' CCCTCTGGCGATTGAATTG $3^{\prime}$ ) (both located within the replicase gene); RSP13 forward primer (5' GTTACAGGGACGGTACAAA 3') and RSP8 reverse primer (5' TCTTGCCTATCAGGGTTGAA 3') (located at the $3^{\prime}$ end of open reading frame [ORF] 3 and the $5^{\prime}$ region of ORF5, respectively). All reagents were from Gibco BRL unless otherwise stated. Purified dsRNAs were used as a template, and the RT-PCR was performed as described previously (54) with the following modifications: $2 \mu \mathrm{l}$ of the dsRNA was denatured by incubating with $20 \mathrm{mM}$ methylmercuric hydroxide (final volume of $9.15 \mu \mathrm{l}$ ) at room temperature for $10 \mathrm{~min}$, and the entire $15-\mu \mathrm{l}$ reverse transcription was used for the PCR reaction.

For direct-binding RT-PCR, leaf tissue was processed as described previously (40). About $0.5 \mathrm{~g}$ of grapevine leaf sample was ground in $5 \mathrm{ml}$ of extraction buffer (37) $(500 \mathrm{mM}$ Tris- $\mathrm{HCl}, \mathrm{pH}$ $8.3 ; 2 \%$ polyvinylpyrrolidone-40; $1 \%$ polyethylene glycol 6000 ; $140 \mathrm{mM} \mathrm{NaCl}$; and $0.05 \%$ Tween 20), and $50 \mu \mathrm{l}$ of the homogenate was added to a $0.5-\mathrm{ml}$ microcentrifuge tube and incubated at $37^{\circ} \mathrm{C}$ for $2 \mathrm{~h}$. After incubation, the tube was washed with PBS-T $(8 \mathrm{~g}$ of $\mathrm{NaCl}, 0.2 \mathrm{~g}$ of $\mathrm{KH}_{2} \mathrm{PO}_{4}, 1.15 \mathrm{~g}$ of $\mathrm{Na}_{2} \mathrm{HPO}_{4}, 0.2 \mathrm{~g}$ of $\mathrm{KCl}$, and $0.05 \%$ Tween 20, pH 7.4) three times and air-dried. The reverse transcription and PCR reagents were added to the tube, and RTPCR was conducted as above.

\section{RESULTS}

Nucleotide sequence and genome organization. The complete genome of GRSPaV was 8,725 nucleotides (nt) in length excluding a $3^{\prime}$ poly(A) tail (GenBank accession number AF026278), as determined from multiple clones (total of 17 clones ranging from 0.4 to $3.1 \mathrm{~kb}$ ) sequenced in both directions. The $5^{\prime}$-end noncoding region was $60 \mathrm{nt}$ in length and the $3^{\prime}$-end noncoding region was $140 \mathrm{nt}$ in length based on the sequences obtained from multiple clones having the same $5^{\prime}$ - and $3^{\prime}$-end sequences. Both noncoding regions were similar to carlaviruses $\left(5^{\prime}\right.$-end sequence had 82 , 66.7, and $80 \%$ similarities to that of PVM, PVX, and ASPV, respectively, and $3^{\prime}$-end sequence had 82, 63.6, and $70.9 \%$ similarities to that of PVM, PVX, and ASPV, respectively, when the Gap program with a gap weight of 5 and a gap length weight of 3 was used) (47).

Six ORFs were identified on one strand of the dsRNA (defining the positive strand of the viral genome) using the frames program of GCG (Fig. 1). ORF1 (nucleotides 61 to 6,546) potentially encodes a polypeptide of 2,161 amino acids (calculated $M_{\mathrm{r}}$ of 244,207) with sequence similarities to viral RNA-dependent RNA polymerases (e.g., it shared 63\% amino acid identity with ORF1 of ASPV). The eight conserved replicase domains (29) and the core sequences GxxxTxxxNT/S and GDD were located at nucleotide positions 6,070 to 6,099 and 6,166 to 6,174, respectively. Methyltransferase (41), helicase (20), and papain-like proteinase domains $(21,31)$ present in Sindbis-like viruses were also located in this polypeptide (Fig. 2). The next three ORFs included ORF2 (nucleotides 6,577 to 7,242 ) with a potential to encode a polypeptide of 221 amino acids $\left(M_{\mathrm{r}}\right.$ of 24,466$)$; ORF3 (nucleotides 7,244 to 7,597) with a potential to encode a polypeptide of 117 amino acids $\left(M_{\mathrm{r}}\right.$ of 12,883); and ORF4 (nucleotides 7,518 to 7,760) with a potential to encode a polypeptide of 80 amino acids $\left(M_{\mathrm{r}}\right.$ of 8,431$)$. These three ORFs had sequence similarities to the triple-gene block common to potexviruses, carlaviruses, ASPV, and some other plant viruses (e.g., they shared 40,40 , and $32 \%$ sequence identities to ORF2, ORF3, and ORF4 of ASPV, respectively). ORF5 (nucleotides 7,770 to

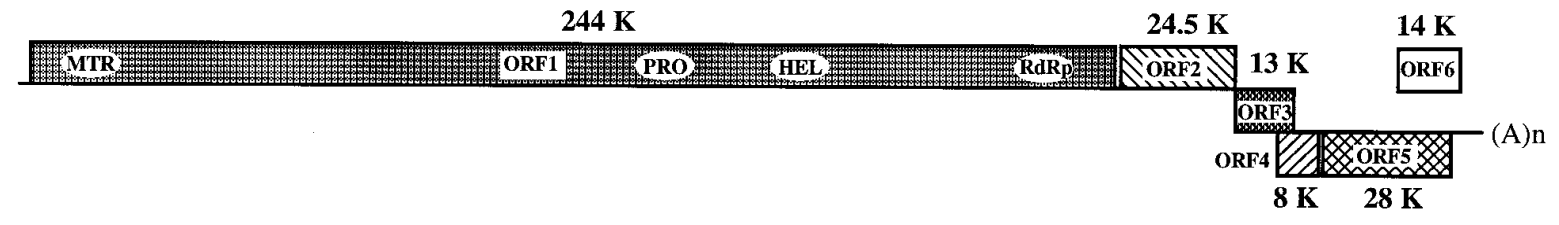

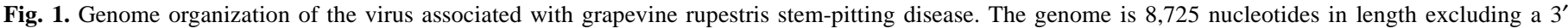

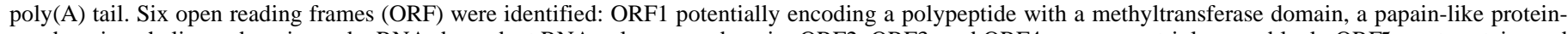

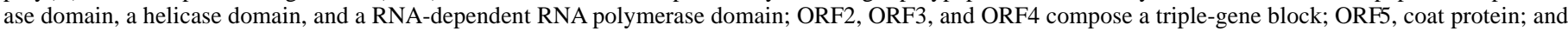
ORF6, unknown function. 
$8,549)$ had the potential to encode for a polypeptide of 259 amino acids $\left(M_{\mathrm{r}}\right.$ of 28,160$)$ and is apparently the coat protein gene. There was $49 \%$ amino acid sequence identity with ASPV coat protein. ORF6 (nucleotides 8,227 to 8,586 ) could potentially encode a polypeptide of 119 amino acids $\left(M_{\mathrm{r}}\right.$ of 14,036), the function of which is not known.

Phylogenetic analysis of GRSPaV. The putative replicase genes of 19 filamentous viruses including GRSPaV were phylogenetically compared and placed into their respective poty-, potex-, carla-, capillo-, tricho-, and closterovirus groups (Fig. 3). The same analysis was done for the putative coat protein genes of 18 viruses with comparable sequence similarities (Fig. 4). In both analyses, GRSPaV was most closely related to ASPV. Both viruses were grouped closer to carlaviruses by replicase homology (Fig. 3) and to potexviruses by coat protein homology (Fig. 4).

RT-PCR detection and association with RSP. A RT-PCR assay was developed to detect GRSPaV (Fig. 5) in grapevines. Among the 62 RSP-positive grapevines tested, 56 and 36 vines were positive with primer pairs RSP2-RSP21 and RSP8-RSP13, respectively. Thirty-two RSP sources were found positive in common, while twenty-four RSP sources were positive by only RSP2-RSP21 and four RSP sources by only RSP8-RSP13. Overall, 60 of the RSP sources tested positive. In these tests, healthy controls tested negative and included $23 \mathrm{~V}$. vinifera cultivars (negative on 'St. George') and 20 grape plants derived from a seedling population. Directbinding PCR (DB-PCR) of samples from five different RSP-

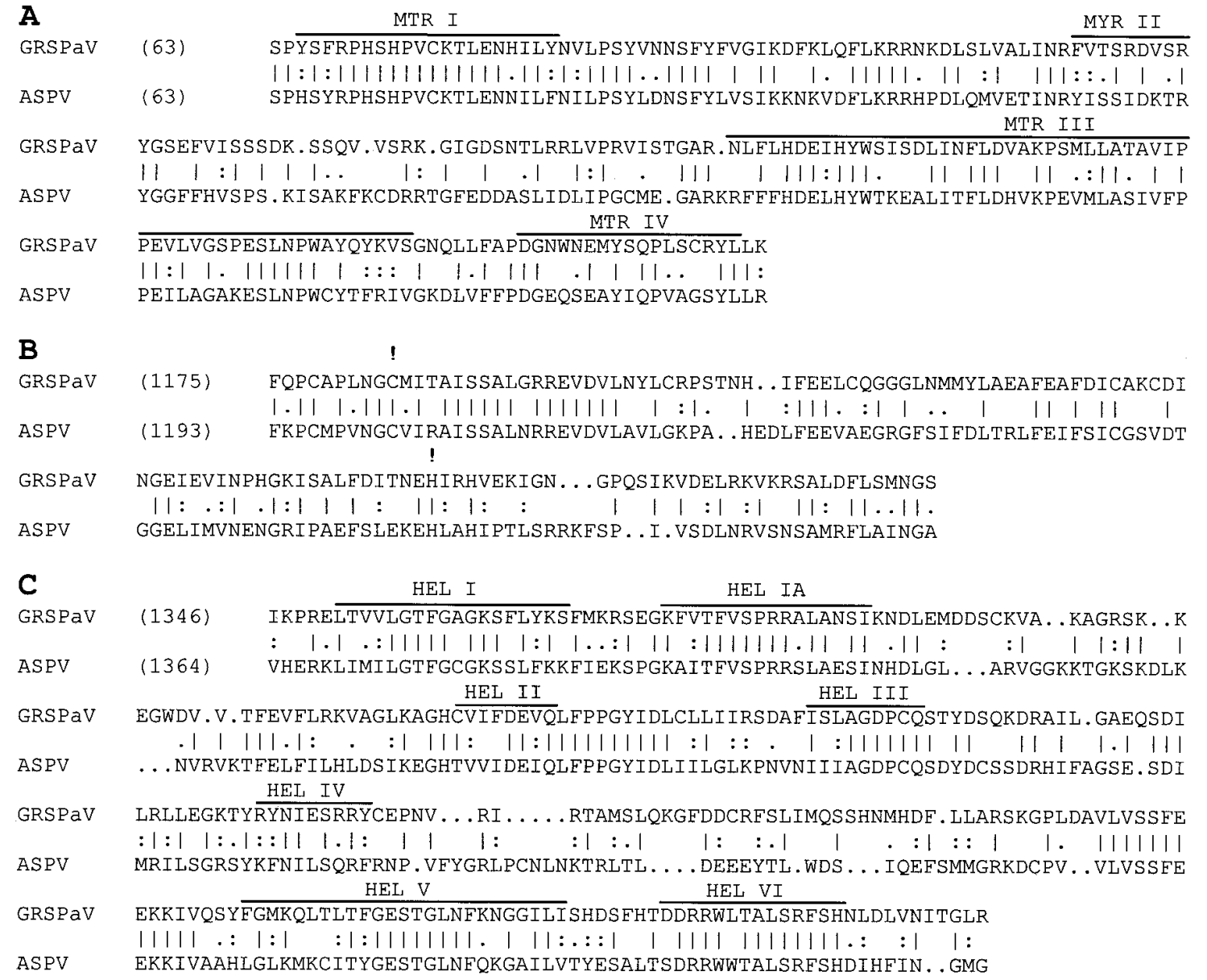

D

GRSPAV

ASPV

GRSPaV

ASPV

GRSPaV

ASPV

GRSPaV

ASPV
RdRp I RdRp II

RdRp III

(1870) I $\overline{\text { FMKSQHCTKFDNRLRVAKAGQTLACFQHAVLVRFAPYMRYIEKKLMQALKP }}$.NFYI $\overline{\text { HSGKGLDELNEWV }}$ |||||||||||||||||||||||||| || |||||||||| | : : | | | ||||||:|:| |1

(1886) IFMKSQLCTKFDNRFRSAKAGQTLACF'QHSVLCRFAPYMRYIESKVTEVL. PKNLYIHSGKNIDDLAAWV
RTRGETGICTESDYEAFDASQDHFILAFELQIMKFLGLPEDLILDYEFIKIHLGSKLGSFSTMRFTGEASTELFNTMANM

(1886) IFMKSQLCTKFDNRFRSAKAGQTLACF'QHSVLCRFAPYMRYIESKVTEVL. PKNLYIHSGKNIDDLAAWV
RTRGETGICTESDYEAFDASQDHFILAFELQIMKFLGLPEDLILDYEFIKIHLGSKLGSFSTMRFTGEASTELFNTMANM

(1886) IFMKSQLCTKFDNRFRSAKAGQTLACF'QHSVLCRFAPYMRYIESKVTEVL. PKNLYIHSGKNIDDLAAWV
RTRGETGICTESDYEAFDASQDHFILAFELQIMKFLGLPEDLILDYEFIKIHLGSKLGSFSTMRFTGEASTELFNTMANM

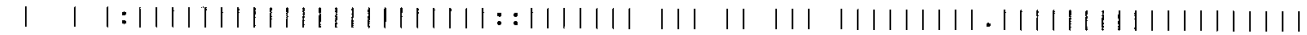
TTSKENGVCTESDYEAFDASQDHFILAFELEVMKFLGLPSDLIADYTFIKTHLGSKLGSFAIMRFTGEASTFLENTMANM

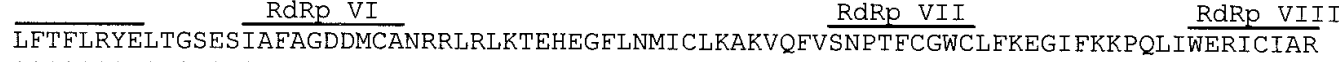

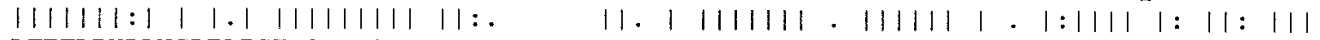
LFTFLRYDLNGREAICFAGDDMCANSRLKVTNRFSNFLDKIKLKAKVQFTAT PT FCGWGLCEHGVFKKPDLVLERLQIAR

EMGNLENCIDNYAIEVSYAYRLGE. LSIEMMTEEEVEAHYNCVRFLVRNKHKMRCSISGLF . EAID* ||||||||||||||||$|::||\quad| .: \quad:|:||:||||||||:| \ldots \mid$ | : . | || |.: ETRNLENCIDNYAIEVSCAYKMGENLNL. YLTPQEVDAHYNCVRFIVQHNHLLKSNIRDLFKGESLPA

Fig. 2. Alignment of the predicted amino acid sequences of the conserved domains of open reading frame (ORF) 1 of grapevine rupestris stem-pittingassociated virus (GRSPaV) and apple stem-pitting virus. A, The putative methyltransferase domain common to Sindbis-like viruses (41). Identical (vertical lines) and similar (colons) residues are indicated. The distances from the beginning of the ORF are indicated as the numbers in parentheses. B, The putative papain-related thiol proteases of positive-strand RNA viruses (21); C, the putative helicase domain (20); and D, the putative RNA-dependent RNA polymerase domain (29). 
infected grapevines gave the same results as RT-PCR using purified dsRNAs as templates. Clarification of tissue extracts with 5\% chloroform and $5 \%$ butanol, before loading into microfuge tubes, improved the sensitivity of DB-PCR detection.

\section{DISCUSSION}

Although the etiology of RSP is unknown, our results suggest we have cloned and characterized an agent closely associated with the disease. The virus was detected by RT-PCR assay in 60 of 62 known RSP sources. Only two RSP-positive plants tested negative by RT-PCR assays. This inconsistency may have been due to (i) the uneven distribution of the virus in the original grapevine sources, which could result in a healthy vine after propagation; (ii) the uneven distribution of the virus in a vine, which could cause a falsenegative test result; (iii) the presence of yet another uncharacterized virus causing stem-pitting symptoms; or (iv) a false positive during biological indexing. We are currently investigating these possibilities.

At this writing, GRSPaV along with ASPV and cherry green ring mottle virus (CGRMV) (53) are unclassified, i.e., not assigned to a virus group. Based on our phylogenetic analysis of replicase and coat protein sequences, these viruses are more closely related to each other than to members of the carla- and potexvirus groups.

Overall, the genome of GRSPaV is most similar to that of ASPV. The $5^{\prime}$ and $3^{\prime}$ noncoding regions of GRSPaV and the replicase amino acid sequences were most similar to those of the carlaviruses (Fig. 3). On the other hand, analysis of coat protein amino acid sequences showed GRSPaV and ASPV to be more closely related to potexviruses (Fig. 4). The different evolutionary subgroup relatedness to potex- or carlaviruses was obtained by phylogenetic analysis of different viral genes. This could be due to different levels of sequence conservation in the genomic loci. Alternatively, it could mean that the two genes were derived from separate sources by a process of recombination among the progenitors of GRSPaV. The analysis of replicase sequences may be a better indicator of its evolutionary relationships, since the viral replicase is the most conserved among positive-strand RNA virus genes (30).

The GRSPaV genome was cloned from a dsRNA that was $8.7 \mathrm{kbp}$ in length. This size is different from that of other previously reported RSP-associated agents $(4,50)$. The genome was organized into six ORFs. Based on similarities to other viruses or conserved

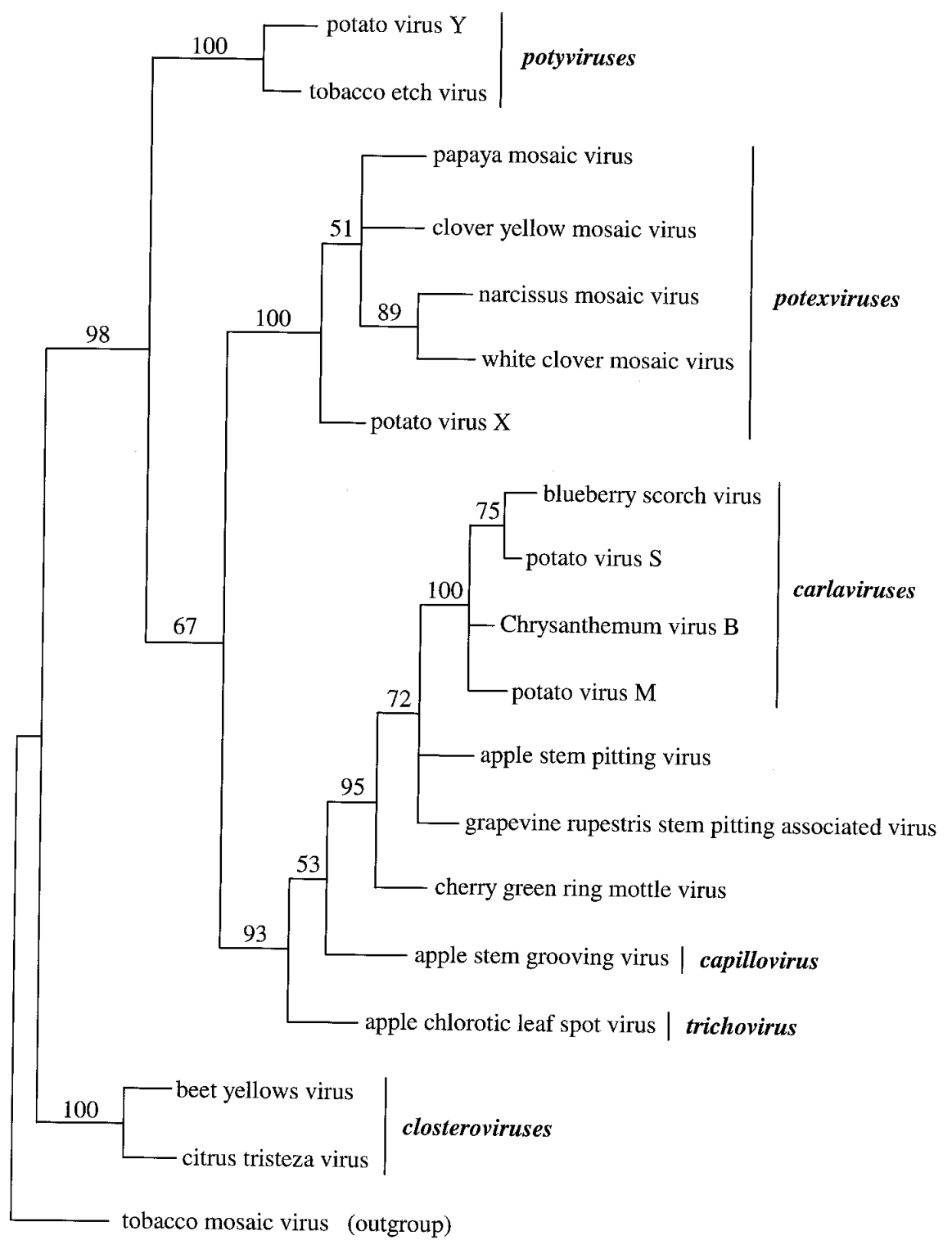

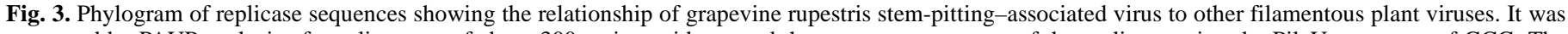

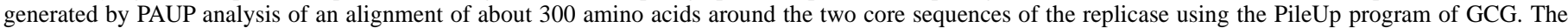
numbers above the branches indicate the bootstrap confidence values. 
motifs, ORF1 was tentatively identified as encoding a polyprotein with a methyltransferase domain, a NTP-binding helicase domain, and a RNA-dependent RNA polymerase domain, which are common to replication-associated proteins. A papain-like proteinase common to positive-strand RNA viruses and might be involved in polyprotein processing was also located within this polyprotein (21). ORF2, ORF3, and ORF4 were identified as a putative triplegene block, which is conserved among carlaviruses and potexviruses (42), and also barley stripe mosaic hordeivirus (23), beet necrotic yellow vein furovirus (7), Nicotiana velutina mosaic virus (38), ASPV (27), and CGRMV (53) and believed to be involved in virus cell-to-cell movement in plants (6). ORF5 was identified as a putative coat protein gene. The function of ORF6 is unknown. The position of this ORF on the genome resembled that of the last ORF in the carlaviruses. Even so, the sequence of ORF6 did not show as much similarity to carlaviruses as is present among carlaviruses in general.

The broad distribution of RSP in grapevines worldwide may be partially due to weak symptom expression in most cultivars, the relatively recent discovery of the disease, and the reliance on woody indicators with a 2 -year incubation period. The PCR-based

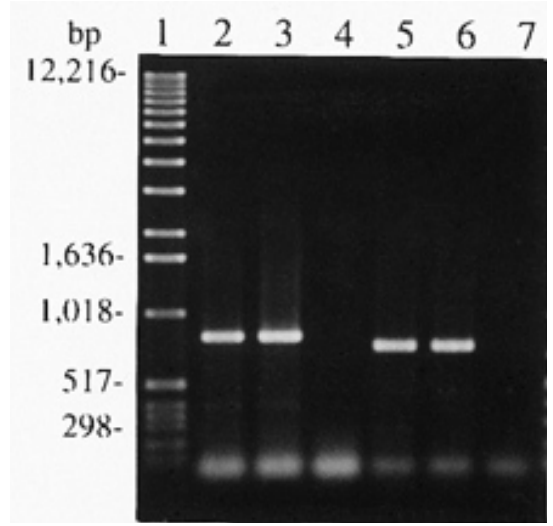

Fig. 5. Reverse-transcription polymerase chain reaction detection of grapevine rupestris stem-pitting-associated virus (GRSPaV) with primer pairs RSP2-RSP21 and RSP8-RSP13. The products were electrophoresed on a $1 \%$ agarose gel. Lane 1, 1-kb DNA ladder (Gibco BRL); lanes 2 and 3, samples from GRSPaV-infected grapevines; lane 4, sample from a healthy grapevine tested using primer pair RSP2RSP21; lanes 5 and 6, samples from GRSPaV-infected grapevines; and lane 7, sample from a healthy grapevine tested using primer pair RSP8-RSP13.

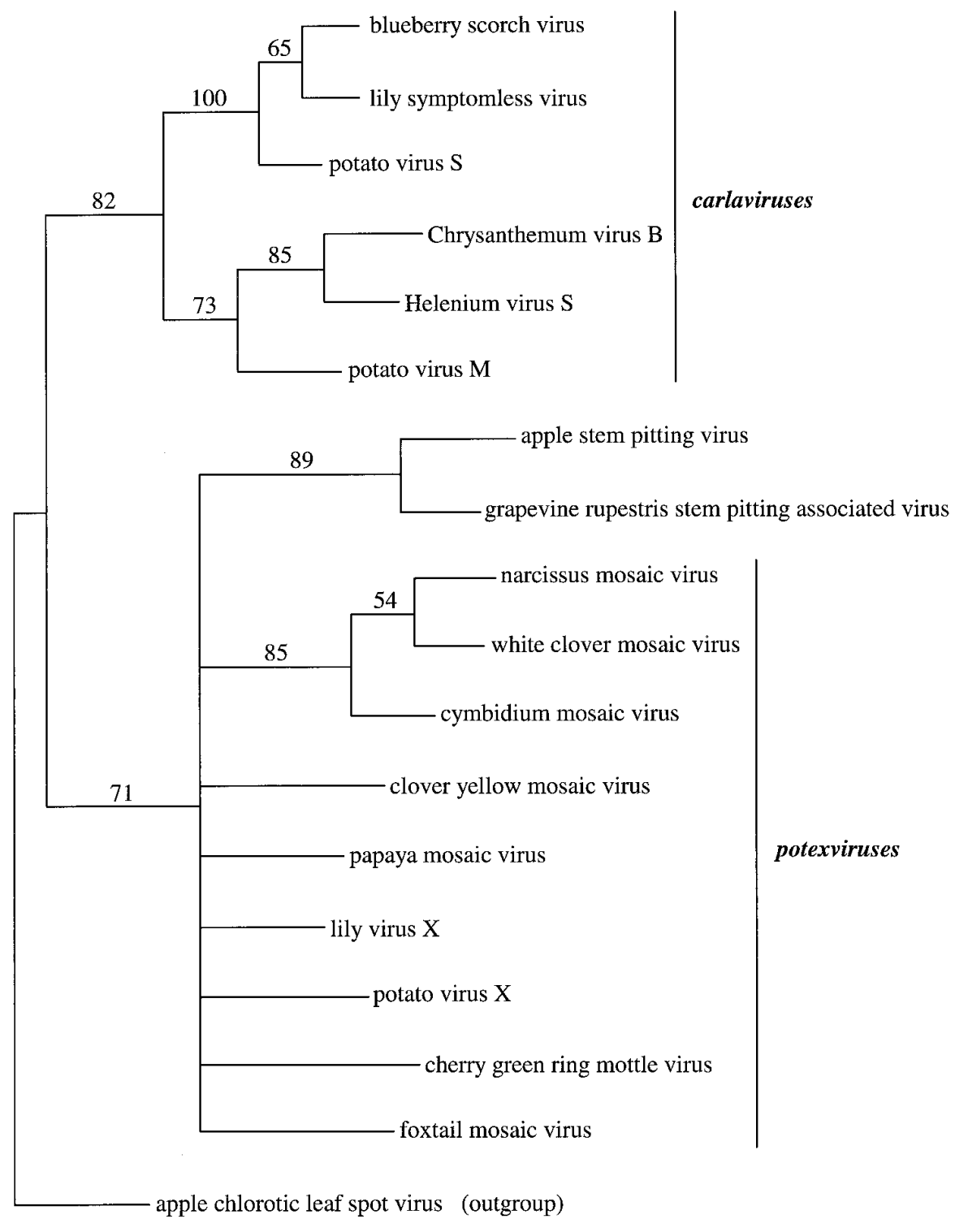

Fig. 4. Phylogram of coat protein sequences showing the relationship of grapevine rupestris stem-pitting-associated virus with apple stem-pitting virus, carlaviruses, and potexviruses. It was generated by PAUP analysis of an alignment of coat protein amino acid sequences using the PileUp program of GCG. The numbers above the branches indicate the bootstrap confidence values. 
detection technique described here will greatly facilitate rapid detection of GRSPaV in field-grown grapevines. Results from RTPCR assays showed a high correlation $(96.7 \%)$ between RSP diseased sources and detection of GRSPaV. RT-PCR products from five different vines were sequenced and confirmed to be of specific viral origin with $82-$ to $99 \%$-nt identities to the sequenced clone. Sequence differences between the RT-PCR products and the clone, and also, the differences between detection efficiencies by primer pairs RSP2-RSP21 and RSP8-RSP13 may indicate the existence of different strains in different grapevines.

Although we have isolated and characterized a virus from a RSP-infected vine and established a good correlation between this virus and the disease by RT-PCR, more research is required to clearly establish a causal relationship.

\section{ACKNOWLEDGMENTS}

This work was partially supported by the American Vineyard Foundation and by the Viticulture Consortium. We thank S. D. Daubert for his critical review of this manuscript.

\section{LITERATURE CITED}

1. Agranovsky, A. A., Koonin, E. V., Boyko, V. P., Maiss, E., Frotschl, R., Lunina, N. A., and Atabekov, J. G. 1994. Beet yellows closterovirus: Complete genome structure and identification of a leader papain-like thiol protease. Virology 198:311-324.

2. Agrios, G. N. 1971. A stem pitting disease of grapevine in Greece. Plant Dis. Rep. 55:869-871.

3. Allison, R. F., Johnson, R. E., and Dougherty, W. G. 1986. The nucleotide sequence of the coding region of tobacco etch virus genomic RNA: Evidence for the synthesis of a single polyprotein. Virology 154:9-20.

4. Azzam, O. I., Gonsalves, D., and Golino, D. A. 1991. Detection of dsRNA in grapevines showing symptoms of rupestris stem pitting disease and the variabilities encountered. Plant Dis. 75:960-964.

5. Bancroft, J. B., Rouleau, M., Johnston, R., Prins, L., and Mackie, G. A. 1991. The complete nucleotide sequence of foxtail mosaic virus RNA. J. Gen. Virol. 72:2173-2181.

6. Beck, D. L., Forster, R. L., Bevan, M. W., Boxen, K. A., and Lowe, S. C. 1990. Infectious transcripts and nucleotide sequence of cloned cDNA of the potexvirus white clover mosaic virus. Virology 177:152-158.

7. Bouzoubaa, S., Ziegler, V., Beck, D., Guilley, H., Richards, K., and Jonard, G. 1986. Nucleotide sequence of beet necrotic yellow vein virus RNA-2. J. Gen. Virol. 67:1689-1700.

8. Cavileer, T. D., Halpern, B. T., Lawrence, D. M., Podleckis, E. V., Martin, R. R., and Hillman, B. I. 1994. Nucleotide sequence of the carlavirus associated with blueberry scorch and similar disease. J. Gen. Virol. 75:711-720.

9. Chia, T. F., Chan, Y. S., and Chua, N. H. 1992. Characterization of cymbidium mosaic virus coat protein gene and its expression in transgenic tobacco plant. Plant Mol. Biol. 18:1091-1099.

10. Ciccarone, A. 1961. La degenerazione infettiva edaltre alterazione della vite. Ital. Agric. 98:900-921.

11. Conti, M., Milne, R. G., Luisoni, E., and Boccardo, G. 1980. A closterovirus from a stem-pitting-diseased grapevine. Phytopathology 70:394-399.

12. Credi, R., and Babini, A. R. 1996. Effect of virus and virus-like infections on the growth of grapevine rootstocks. Adv. Hortic. Sci. 10:95-98.

13. Engelbrecht, D. J., and Nel, A. C. 1971. A graft-transmissible stem grooving of grapevines in the Western Cape province (South Africa) resembling legno riccio (rugose wood). Phytophylactica 3:93-96.

14. Foster, G. D., Millar, A. W., Meehan, B. M., and Mills, P. R. 1990. Nucleotide sequence of the $3^{\prime}$-terminal region of helenium virus S RNA. J. Gen. Virol. 71:1877-1880

15. Foster, G. D., and Mills, P. R 1992. The 3'-nucleotide sequence of an ordinary strain of potato virus S. Virus Genes 6:213-220.

16. German, S., Candresse, T., Lanneau, M., Huet, J. C., Pernollet, J. C., and Dunez, J. 1990. Nucleotide sequence and genomic organization of apple chlorotic leaf spot closterovirus. Virology 179:104-112.

17. Goheen, A. C. 1988. Rupestris stem pitting. Page 53 in: Compendium of Grape Disease. R. C. Pearson and A. C. Goheen, eds. The American Phytopathological Society, St. Paul, MN.

18. Goheen, A. C. 1988. Virus diseases and grapevine selection. Am. J. Enol. Vitic. 40:67-72.

19. Golino, D. A. 1993. Potential interactions between rootstocks and grapevine latent viruses. Am. J. Enol. Vitic. 44:148-152.

20. Gorbalenya, A. E., Koonin, E. V., Donchenko, A. P., and Blinov, V. M.
1988. A conserved NTP-motif in putative helicases. Nature 333:22.

21. Gorbalenya, A. E., Koonin, E. V., and Lai, M. M. C. 1991. Putative papain-related thiol proteases of positive-strand RNA viruses. FEBS (Fed. Eur. Biochem. Soc.) Lett. 288:201-205.

22. Graniti, A., and Ciccarone, A. 1961. Osservazioni su alterazioni virosiche e virus-simili della vite in Puglia. Not. Mal. Piante 55:99-102.

23. Gustafson, G., and Armour, S. L. 1986. The complete nucleotide sequence of RNA B from the type strain of barley stripe mosaic virus. Nucleic Acids Res. 14:3895-3909.

24. Hewitt, W. B., and Neja, R. 1971. Grapevine bark and wood pitting disease found in California. Plant Dis. Rep. 55:860-861.

25. Huisman, M. J., Linthorst, H. J., Bol, J. F., and Cornelissen, J. C. 1988. The complete nucleotide sequence of potato virus $\mathrm{X}$ and its homologies at the amino acid level with various plus-stranded RNA viruses. J. Gen. Virol. 69:1789-1798.

26. Ikeda, R., Watanabe, E., Watanabe, Y., and Okada, Y. 1993. Nucleotide sequence of tobamovirus $\mathrm{Ob}$ which can spread systemically in $\mathrm{N}$ gene tobacco. J. Gen. Virol. 74:1939-1944.

27. Jelkmann, W. 1994. Nucleotide sequence of apple stem pitting virus and of the coat protein gene of a similar virus from pear associated with vein yellows disease and their relationship with potex- and carlaviruses. J. Gen. Virol. 75:1535-1542.

28. Karasev, A. V., Boyko, V. P., Gowda, S., Nikolaeva, O. V., Hilf, M. E., Koonin, E. V., Niblett, C. L., Cline, K., Gumpf, D. J., Lee, R. F., Garnsey, S. M., Lewandowski, D. J., and Dawson, W. O. 1995. Complete sequence of the citrus tristeza virus RNA genome. Virology 208:511-520.

29. Koonin, E. V. 1991. The phylogeny of RNA-dependent RNA polymerases of positive-strand RNA viruses. J. Gen. Virol. 72:2197-2206.

30. Koonin, E. V., and Dolja, V. V. 1993. Evolution and taxonomy of positive-strand RNA viruses: Implications of comparative analysis of amino acid sequences. Crit. Rev. Biochem. Mol. Biol. 28:375-430.

31. Lawrence, D. M., Rozanov, M. N., and Hillman, B. I. 1995. Autocatalytic processing of the 223-kDa protein of blueberry scorch carlavirus by a papain-like proteinase. Virology 207:127-135.

32. Levay, K., and Zavriev, S. 1991. Nucleotide sequence and gene organization of the $3^{\prime}$-terminal region of chrysanthemum virus B genomic RNA. J. Gen. Virol. 72:2333-2337.

33. MacKenzie, D. J., Tremaine, J. H., and Stace-Smith, R. 1989. Organization and interviral homologies of the 3'-terminal portion of potato virus S RNA. J. Gen. Virol. 70:1053-1063.

34. Memelink, J., van der Vlugt, C. I., Linthorst, H. J., Derks, A. F., Asjes, C. J., and Bol, J. F. 1990. Homologies between the genomes of a carlavirus (lily symptomless virus) and a potexvirus (lily virus $\mathrm{X}$ ) from lily plants. J. Gen. Virol. 71:917-924.

35. Meng, B., and Gonsalves, D. 1997. Nucleotide sequence and genomic organization of grapevine Rupestris stem pitting-associated virus and its detection by RT-PCR. (Abstr.) Phytopathology 87:S65-S66.

36. Monette, P. L., James, D., and Godkin, S. E. 1989. Double-stranded RNA from rupestris stem pitting-affected grapevines. Vitis 28:137-144.

37. Nolasco, G., de Blas, C., Torres, V., and Ponz, F. 1993. A method combining immunocapture and PCR amplification in a microtiter plate for the detection of plant viruses and subviral pathogens. J. Virol. Methods 45:201-218.

38. Randles, J. W., and Rohde, W. 1990. Nicotiana velutina mosaic virus: Evidence for a bipartite genome comprising $3 \mathrm{~kb}$ and $8 \mathrm{~kb}$ RNAs. J. Gen. Virol. 70:1861-1869.

39. Raynolds, A. G., Lanterman, W. S., and Wardle, D. A. 1997. Yield and berry composition of five Vitis cultivars as affected by rupestris stem pitting virus. Am. J. Enol. Vitic. 48:449-458.

40. Rowhani, A., Maningas, M. A., Lile, L. S., Daubert, S. D., and Golino, D. A. 1995. Development of a detection system for viruses of woody plants based on PCR analysis of immobilized virions. Phytopathology 85:347-352.

41. Roznanov, M. N., Koonin, E. V., and Gorbalenya, A. E. 1992. Conservation of the putative methyltransferase domain: A hallmark of the "Sindbis-like" supergroup of positive-strand RNA viruses. J. Gen. Virol. 73:2129-2134

42. Rupasov, V. V., Morozov, S.-Y., Kanyuka, K. V., and Zavriev, S. K. 1989. Partial nucleotide sequence of potato virus M RNA shows similarities to potexviruses in gene arrangement and the encoded amino acid sequences. J. Gen. Virol. 70:1861-1869.

43. Sato, K., Yoshikawa, N., and Takahashi, T. 1993. Complete nucleotide sequence of the genome of an apple isolate of apple chlorotic leaf spot virus. J. Gen. Virol. 74:1927-1931.

44. Sit, T. L., Abouhaidar, M. G., and Holy, S. 1989. Nucleotide sequence of papaya mosaic virus RNA. J. Gen. Virol. 70:2325-2331.

45. Sit, T. L., White, K. A., Holy, S., Padmanabhan, U., Eweida, M., Hiebert, M., Mackie, G. A., and AbouHaidar, M. G. 1990. Complete nucleotide sequence of clover yellow mosaic virus RNA. J. Gen. Virol. 71:1913-1920.

46. Takamatsu, S., Lin, B., Furuta, H., and Makara, K. 1994. RT-PCR medi- 
ated cloning and sequence analysis of lily symptomless virus coat protein gene. Ann. Phytopathol. Soc. Jpn. 60:487-490.

47. Teresa, M., Haylor, M., Brunt, A. A., and Coutts, R. H. 1990. Conservation of the $3^{\prime}$ terminal nucleotide sequence in five carlaviruses. Nucleic Acids Res. 18:6127.

48. Thole, V., Dalmay, T., Burgyan, J., and Balazs, E. 1993. Cloning and sequencing of potato virus Y (Hungarian isolate) genomic RNA. Gene 123:149-156.

49. Valverde, R. A., Nameth, S. T., and Jordan, R. L. 1990. Analysis of double-stranded RNA for plant virus diagnosis. Plant Dis. 74:255-258.

50. Walter, M. H., and Cameron, H. R. 1991. Double-stranded RNA isolated from grapevines affected by rupestris stem pitting disease. Am. J. Enol. Vitic. 42:175-179.

51. Yoshikawa, N., Sasaki, E., Kato, M., and Takahashi, T. 1992. The nu- cleotide sequence of apple stem grooving capillovirus genome. Virology 191:98-105.

52. Zavriev, S. K., Kaniuka, K. I., and Levai, K. E. 1991. Complete nucleotide sequence of genomic RNA of the potato M-virus. Mol. Biol. (Mosk.) 25:761-769.

53. Zhang, Y.-P., Kirkpatrick, B. C., and Uyemoto, J. K. 1998. cDNA cloning and molecular characterization of sour cherry green ring mottle virus. J. Gen. Virol. 79:2275-2281.

54. Zhang, Y.-P., Uyemoto, J. K., and Kirkpatrick, B. C. 1998. A rapid, small scale procedure for extracting virus, viroid, MLO, and bacterial nucleic acids from plants for analysis by PCR. J. Virol. Methods 71:45-50.

55. Zuidema, D., Linthorst, H. J., Huisman, M. J., Asjes, C. J., and Bol, J. F. 1989. Nucleotide sequence of narcissus mosaic virus RNA. J. Gen. Virol. 70:267-276. 